\title{
Estimation of Immunoglobulin A, Immunoglobulin G, and Immunoglobulin M Antibody Levels in Laboratory Mice Balb/c Infected with Entamoeba histolytica and Treatment with Aqueous Extracts of Cyperus rotundus and Thymus serpyllum
}

\author{
Farhan K. Hussein ${ }^{1 *}$, Ashraf J. Mahmoud ${ }^{1}$, Buthainah J. Yousif ${ }^{2}$ \\ ${ }^{1}$ Department of Biology, College of Education for Women, Tikrit University, Tikrit, Iraq, ${ }^{2}$ Department of Biology, College of Education for Pure \\ Sciences, Tikrit University, Tikrit, Iraq
}

\section{${ }^{\star}$ Corresponding author: \\ Farhan K. Hussein, \\ Department of Biology, \\ College of Education for \\ Women, \\ Tikrit University, Tikrit, Iraq \\ E-mail: farhan.bio@yahoo. \\ com}

Received: 18 September 2019

Accepted: 26 January 2020

Published: 30 June 2020

\section{DOI}

10.25156/pji.v10n1y2020.pp126-129

\begin{abstract}
A B S T R A C T
Sixty Balb/c mice (Mus musculus) were used in the present study. It was conducted out in the animal house of the Department of Biology/College of Education for Women. The mice were infected with Entamoeba histolytica isolated from positive stool samples obtained from children in pediatric hospital in Kirkuk city governorate followed by treatment with aqueous extract of Cyperus rotundus and Thymus serpyllum. Results revealed a significant increase of $P<0.05$ in immunoglobulin A, immunoglobulin $G_{,}$, and immunoglobulin $M$ antibody levels among infected mice when it was compared with the control and treated groups of aqueous extracts of studied plant. This indicates the efficacy of these extracts as treatment.
\end{abstract}

Keywords: Antibody levels; Entamoeba histolytica; Thymus serpyllum; Cyperus rotundus; Dysentery

\section{INTRODUCTION}

Entamoeba histolytica is an enteric protozoan parasite that causes amebiasis (Ali, 2015). It is the third leading reason for death from parasitic diseases worldwide after malaria and schistosomiasis (Mortimer and Chadee, 2010; Ghasemi et al., 2015). It is estimated that it affects nearly 50 million people worldwide, causing deaths of nearly 40,000-100,000 people annually (Inam et al., 2016; Pineda and Perdomo, 2017). E. histolytica is prevalent worldwide, being most spread in tropical and subtropical regions (Al-Areeqi et al., 2017; Yimer et al., 2017; Sastry and Bhat, 2018), especially in developing countries (Peterson et al., 2011; Gwairgi and Ghildyal, 2018). There are more than 20 species of Entamoeba, with varying disease-causing potential and host specificity (Nozaki and Bhattacharya, 2015). Unfortunately, many species of Entamoeba are morphologically indistinguishable from E. histolytica, including the potentially pathogenic but rare E. nuttalli (Levecke et al., 2015), as well as many nonpathogenic species of Entamoeba, including Entamoeba dispar, Entamoeba moshkovskii, and Entamoeba bangladeshi Nozaki and Bhattacharya, 2015; Jirků-pomajbÍková et al., 2016).
Thymus serpyllum is an important medicinal herb because it contains antimicrobial agents and is rich in various active substances such as thymol, carvacrol, paracymene, and terpinene (Nabavi et al., 2015). Cyperus rotundus is a perennial medicinal plant and is used globally in traditional medicine to treat various diseases (Singh et al., 2012; Lydia and Sudarsanam, 2014; Peerzada et al., 2015). The plant contains many active compounds such as flavonoid, saponin, glycosides, alkaloid, starch, monoterpene, and many other secondary metabolites (Sivapalan and Jeyadevan, 2012; Singh et al., 2012; Al-Snafi, 2016), as many studies have proven it to be analgesic, anti-allergic, anti-inflammatory, anti-diarrheal, anti-reactive, and anti-worm (Kamala et al., 2018). There are five types of immunoglobulins, A, D, E, G, and $\mathrm{M}$ and the first four species are found in the immune response to parasites (Abd-Alla et al., 2006; Macpherson et al., 2008).

\section{MATERIALS AND METHODS}

\section{Isolates of E. histolytica}

E. histolytica was isolated from positive stool samples obtained from children in pediatric hospital in Kirkuk city 
governorate from a period between November 2018 and April 2019. Children selected for this study were usually suffering from diarrhea, dysentery, and vomiting. The sterile plastic container was used during the transport of stool from the laboratory of parasitology in the pediatric hospital to the advanced laboratory of parasitology in the Department of Biology/College of Education for Women. The stool samples were examined using two direct smears method first in normal saline $0.9 \%$ and the second one in Lugol's iodine 1\% to the screening on E. histolytica trophozoites and cysts stage, respectively (Cheesbrough, 2005).

\section{Experimental Design}

Sixty mice were used to conduct the experiment. These mice were divided into 10 groups, each with six mice. The mean of the number of cysts or trophozoite stages of the parasite was then calculated for each group of infected mice before treatment. Treatment with aqueous extracts was given orally and with drinking water at specific doses. The percentage of parasite efficacy was calculated for each of the infected mice (positive control) and the groups of mice 25 days after giving them the treatment, according to the following equation:

Parasite efficacy $=$ (number of cysts or trophozoite stages post-treatment/number of cysts or trophozoite stages pre-treatment) $\times 100$ (AL-Mukhtar and Barwari, 2008).

Group 1: Six mice each was orally administered normal saline for 25 days.

Group 2: Positive control, mice were infected with E. histolytica according to Lemee et al. (2000).

Group 3: Six mice each were administered $2 \mathrm{mg} / \mathrm{ml}$ b. wt. of the fresh aqueous extracts of C. rotundus for 25 consecutive days

Group 4: Six mice each was administered $3 \mathrm{mg} / \mathrm{ml}$ b. wt. of the fresh aqueous extracts of C. rotundus for 25 consecutive days

Group 5: Six mice each was administered $4 \mathrm{mg} / \mathrm{ml}$ b. wt. of the fresh aqueous extracts of C. rotundus for 25 consecutive days

Group 6: Six mice each was administered $5 \mathrm{mg} / \mathrm{ml}$ b. wt. of the fresh aqueous extracts of $C$. rotundus for 25 consecutive days.

Group 7: Six mice each was administered $2 \mathrm{mg} / \mathrm{ml} \mathrm{b}$. wt. of the fresh aqueous extracts of $T$. serpyllum for 25 consecutive days.
Group 8: Six mice each was administered $3 \mathrm{mg} / \mathrm{ml} \mathrm{b}$. wt. of the fresh aqueous extracts of T. serpyllum for 25 consecutive days.

Group 9: Six mice each was administered $4 \mathrm{mg} / \mathrm{ml} \mathrm{b}$. wt. of the fresh aqueous extracts of T. serpyllum for 25 consecutive days.

Group 10: Six mice each was administered $5 \mathrm{mg} / \mathrm{ml}$ b. wt. of the fresh aqueous extracts of T. serpyllum for 25 consecutive days.

\section{Statistical Analysis}

The statistical analysis system (SAS 2010) was used in this study the effect of the different factors in the studied traits. The differences between the means were compared with the least significant difference of LSD, and the percentages were compared with the Chi-square test.

\section{RESULTS AND DISCUSSION}

\section{Estimation of Immunoglobulin's Level}

The study showed differences in the level of $\operatorname{IgG}, \operatorname{IgA}$, and IgM in mice infected with E. histolytica compared to the control group [Table 1] and treatment with the aqueous extracts of $C$. rotundus in different concentrations [Table 2] when compared with the control group and the concentration of $\mathrm{mg} / \mathrm{dl}$ was studied. Statistical analysis showed significant differences between the different groups at $P=0.05$.

Several studies have indicated that $\operatorname{IgM}, \operatorname{IgG}$, and $\operatorname{IgA}$ antibodies have increased in acute and chronic cases of E. histolytica infection (Al Quraishi and Al-Sultany, 2017).

Table 1: Levels of immunoglobulin IgM, IgG, and IgA in mice serum infected with Entamoeba histolytica and control group

\begin{tabular}{lcc}
\hline Types of immunoglobulin & Infected mice & Control \\
\hline $\lg A$ & $544.30 \pm 55.1^{*}$ & $104.65 \pm 8.20$ \\
$\operatorname{lgG}$ & $1610.5 \pm 85.0$ & $530.6 \pm 19.11$ \\
$\lg M$ & $366.00 \pm 61.1$ & $211.88 \pm 10.88$ \\
\hline
\end{tabular}

("Mean \pm SD). IgA: Immunoglobulin A, IgG: Immunoglobulin G, IgM: Immunoglobulin M

Table 2: Fluctuation of different immunoglobulin levels after using of aqueous extract of Cyperus rotundus in different concentrations in mice infected with Entamoeba histolytica

\begin{tabular}{|c|c|c|c|}
\hline \multirow{2}{*}{$\begin{array}{l}\text { Concentrations of } \\
\text { aqueous extract } \\
\text { of Cyperus } \\
\text { rotundus }(\mathrm{mg} / \mathrm{ml})\end{array}$} & \multicolumn{3}{|c|}{ Immunoglobulin } \\
\hline & $\lg A$ & IgG & $\lg M$ \\
\hline 2 & $112.80 \pm 11.26^{*}$ & $537.3 \pm 11.91$ & $255.10 \pm 24.1$ \\
\hline 3 & $124.23 \pm 10.80$ & $539.2 \pm 31.9$ & $264.06 \pm 19.12$ \\
\hline 4 & $127.70 \pm 25.7$ & $616.8 \pm 18.91$ & $273.55 \pm 12.89$ \\
\hline 5 & $128.10 \pm 32.5$ & $698.8 \pm 27.8$ & $305.22 \pm 16.69$ \\
\hline
\end{tabular}

( ${ }^{*}$ Mean \pm SD). IgA: Immunoglobulin A, IgG: Immunoglobulin G, IgM: Immunoglobulin M 


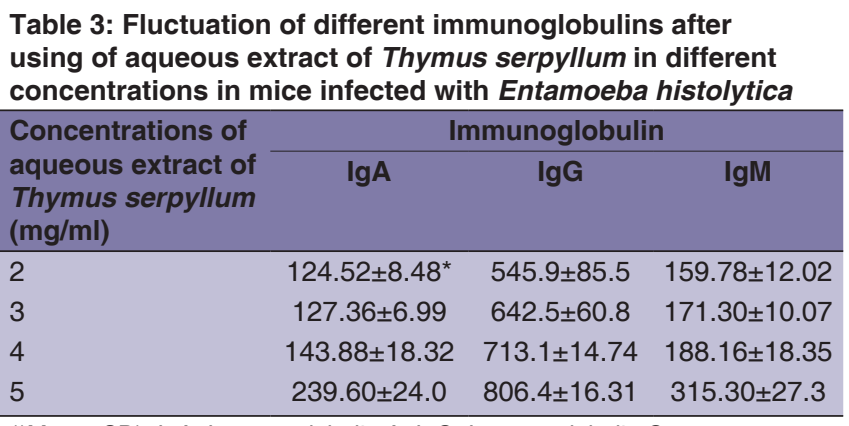

(*Mean \pm SD). IgA: Immunoglobulin A, IgG: Immunoglobulin G, IgM: Immunoglobulin M

The current study the an increase in the $\operatorname{IgM}, \operatorname{IgG}, \operatorname{IgA}$, of infection with E. histolytica, this result is close to ALKahfaji (2010) who recorded an increase in the IgM, $\operatorname{IgG}, \operatorname{Ig} \mathrm{A}$, and $\operatorname{IgE}$ antibodies in the infected patients $\mathrm{E}$. histolytica compared with the control group. An increase in the $\operatorname{IgM}, \operatorname{IgG} \operatorname{IgA}$, and $\operatorname{IgE}$ antibodies in the infected patients E. histolytica compared with the control group.

In Kirkuk, Anwar (2014) observed an increase in IgM, $\mathrm{IgG}$, and IgA levels in people who E. histolytica parasites. Another study indicated an increase in the level of IgA and IgG antibodies in animals infected with parasite while no significant differences were observed in IgM (Houpt et al., 2002; Jarillo-Luna et al., 2002). In the present study, the results showed a significant increase of $P<0.05$ in $\operatorname{IgA}, \operatorname{IgG}$, and $\operatorname{IgM}$ antibody levels in mice infected with E. histolytica compared to levels in control groups.

Animals treated with different concentrations of 2, 3, and $4 \mathrm{mg} / \mathrm{ml}$ of aqueous extract of C. rotundus plant showed a decrease in the level of antibodies and increased at a concentration of $5 \mathrm{mg} / \mathrm{ml}$. This may be due to the important therapeutic role of this plant extract through its active substances such as glycosides, resins, and alkaloids, in addition to the acidic environment, these factors led to the reduction of the parasite numbers in the lumen of the large intestine and thus the damage caused by the parasite and thus the reduction of the acute inflammatory state due to the low level of antibodies to the serum of animals (ALKahfaji, 2010). Concentrations 2 and 3 were to be better compared to control and treated groups.

As for the groups treated with aqueous extract of T. serpyllum plant in different concentrations 2,3 , and $4 \mathrm{mg} /$ $\mathrm{ml}$, it was observed that the level of antibodies decreased and increased at a concentration of $5 \mathrm{mg} / \mathrm{ml}$ [Table 3]. The decrease in the level of antibodies may be due to the fact that its essential oil contains active compounds such as thymol and carvacrol which have an effect on the disappearance of the parasite within the large intestine and therefore the decrease in the level of antibodies treated with aqueous extract of T. serpyllum and the return of the immune status to the normal level and the level of serum proteins gradually decreased, and the concentrations of 2,3 , and $4 \mathrm{mg} / \mathrm{ml}$ gave comparable results compared with groups while increased at a concentration of $5 \mathrm{mg} / \mathrm{ml}$.

\section{CONCLUSION}

The results of the present study showed a significant increase $\operatorname{IgG}$, IgM, and IgA levels in mice infected with E. histolytica in general, compared to the control and treated groups of aqueous extracts of C. rotundus and T. serpyllum. This indicates the efficacy of these extracts as treatment and after further studies on all active ingredients in both plants.

\section{ACKNOWLEDGMENT}

First of all, I would like to thank the creator, Allah, for everything, this article would not have been presented in this fashion without mercy of Allah and peace and mercy upon his messenger prophet Muhammed. I would like to express my thanks and indebtedness to my University of Tikrit, College of Education for Women/Department of Biology. I would like to express my appreciation to all doctors and laboratory staff in the pediatric hospital in Kirkuk city also my deep appreciation to all staff members in the department of parasitology in the pediatric hospital in Kirkuk city.

\section{ETHICAL APPROVAL}

Ethical approval has been collected and preserved by the authors concerning standards or university standards.

\section{REFERENCES}

Abd-Alla, M. D., T. Jackson, T. Rogers, S. Reddy and J. I. Ravdin. 2006. Mucosal immunity to asymptomatic Entamoeba histolytica and Entamoeba dispar infection is associated with a peak intestinal anti-lectin immunoglobulin a antibody response. Infect. Immun. 74: 3897-3903.

Al Quraishi, M. A. and S. H. Al-Sultany. 2017. Immunoglobulin profile of $E$. histolytica and E. dispar in human sera. J. Bio. Innov. 6: 203-213.

Al-Areeqi, M. A., H. Sady, H. M. Al-Mekhlafi, T. S. Anuar, A. H. Al-Adhroey, W. M. Atroosh and Y. L. Lau. 2017. First molecular epidemiology of Entamoeba histolytica, E. dispar and E. moshkovskii infections in Yemen: Different species-specific associated risk factors. Trop. Med. Int. Health. 22: 493-504.

Ali, I. K. M. 2015. Intestinal amebae. Clin. Lab. Med. 35: 393-422.

AL-Kahfaji, M. S. A. 2010. Some Immunological Criteria for Patient Infected with Entamoeba histolytica and Histological Changes in White Mice. In: Thesis for Degree of Master in Biology College of Science for Women, University of Babylon, Babylon. 
AL-Mukhtar, A. M. and W. J. Barwari. 2008. Effectiveness of albendazole against viability of Entamoeba histolytica in mice and rabbits. Ann. Coll. Med. Mosul. 34: 64-68.

Al-Snafi, A. E. 2016. A review on Cyperus rotundus a potential medicinal plant. IOSR J. Pharm. 6: 32-48.

Anwar, S. A. 2014. Epidemiological and Immunological Study of Infection with E. histolytica and E. dispar Among Children Attending Kirkuk Pediatric Hospital with Trial Treatment by Using Deferoxamine and Zinc as Alternative Treatment for Amoebiasis. In: Thesis for Doctoral Degree (Ph.D.), College of Pure Science, University of Tikrit, Tikrit.

Cheesbrough, M. 2005. District Laboratory Practice in Tropical Countries. $2^{\text {nd }}$ ed. Cambridge University Press, Cambridge, United Kingdom. p200-202.

Ghasemi, E., M. Rahdar and M. Rostami. 2015. Prevalence of Entamoeba histolyticaldispar in drinking water in the city of Shush, Khuzestan Province in 2011. Int. J. Curr. Microbiol. App. Sci. 4: 582-588.

Gwairgi, M. A. and R. Ghildyal. 2018. Nuclear transport in Entamoeba histolytica: Knowledge gap and therapeutic potential. Parasitology. 145: 1378-1387.

Houpt, E. R., D. J. Glembocki, T. G. Obrig, C. A. Moskaluk, L. A. Lockhart, R. L. Wright and W. A. Petri. 2002. The mouse model of amebic colitis reveals mouse strain susceptibility to infection and exacerbation of disease by $\mathrm{CD}_{4}+\mathrm{T}$ cells. J. Immunol. 169: 4496-4503.

Inam, A., S. Mittal, M. S. Rajala, F. Avecilla and A. Azam. 2016. Synthesis and biological evaluation of 4-(2-(dimethylamino) ethoxy) benzohydrazide derivatives as inhibitors of Entamoeba histolyica. Eur. J. Med. Chem. 124: 445-455.

Jarillo-Luna, R. A., R. Campos-Rodrıguez and V. Tsutsumi. 2002. Entamoeba histolytica: Immunohistochemical study of hepatic amoebiasis in mouse. Neutrophils and nitric oxide as possible factors of resistance. Exp. Parasitol. 101: 40-56.

Jirků-pomajbĺková, K., I. Čepička, B. Kalousová, M. Jirků, F. Stewart, B. Levecke and K. J. Petrželková. 2016. Molecular identification of Entamoeba species in savanna woodland chimpanzees (Pan troglodytes schweinfurthii). J. Parasitol. 143: 741-748.

Kamala, A., S. K. Middha and C. S. Karigar. 2018. Plants in traditional medicine with special reference to Cyperus rotundus L.: A review. 3 Biotech. 8: 309.

Lemee, V., I. Zaharia, G. Nevez, M. Rabodonirina, J. J. Ballet and L. Favennec. 2000. Metronidazole and albendazole susceptibility of 11 clinical isolates of Giardia duodenalis from France. J. Ant. Chem. 46: 819-821.

Levecke, B., P. Dorny, F. Vercammen, L. G. Visser, M. Van Esbroeck, J. Vercruysse, J., and Verweij, J. J. 2015. Transmission of Entamoeba nuttalli and Trichuris trichiura from nonhuman primates to humans. Emerg. Infect. Dis. 21: 1871.

Lydia, J. and D. Sudarsanam. 2014. Docking of a Cyperus rotundus compound '15-Hydroxy-4-oxo-10-pentadecynoic acid lactone' with anti-diabetic drug targets: A comparative study. Int. J. Fund. Appl. Sci. 3: 17-21.

Macpherson, A., K. McCoy, F. Johansen and P. Brandtzaeg. 2008. The immune geography of IgA induction and function. Mucosal Immunol. 1: 11-22.

Mortimer, L. and K. Chadee. 2010. The immunopathogenesis of Entamoeba histolytica. Exp. Parasitol. 126: 366-380.

Nabavi, S. M., A. Marchese, M. Izadi, V. Curti, M. Daglia and S. F. Nabavi. 2015. Plants belonging to the genus thymus as antibacterial agents: From farm to pharmacy. Food Chem. 173: 339-347.

Nozaki, T. and A. Bhattacharya. 2015. Amebiasis: Biology and pathogenesis of Entamoeba. Springer, Berlin, Germany.

Peerzada, A. M., H. H. Ali, M. Naeem, M. Latif, A. H. Bukhari and A. Tanveer. 2015. Cyperus rotundus L.: Traditional uses, phytochemistry, and pharmacological activities. J. Ethnopharmacol. 174: 540-560.

Peterson, K. M., U. Singh and W. A. Jr. Petri. 2011. Enteric amebiasis. In: Tropical Infectious Diseases: Principles, Pathogens and Practice. WB Saunders, Philadelphia, Pennsylvania, PA. p614-622.

Pineda, E. and D. Perdomo. 2017. Entamoeba histolytica under oxidative stress: What countermeasure mechanisms are in place? Cells. 6: 44.

Sastry, A. S. and S. Bhat. 2018. Essentials of Medical Parasitology. $2^{\text {nd }}$ ed. Jaypee Brothers, Medical Publishers Pvt. Limited, New Delhi.

Singh, N., B. R. Pandey, P. Verma, M. Bhalla and M. Gilca. 2012. Phyto-pharmacotherapeutics of Cyperus rotundus Linn. (Motha): An overview. Indian J. Nat. Prod, Resour. 3: 467-476.

Sivapalan, S. R. and P. Jeyadevan. 2012. Physico-chemical and phytochemical study of rhizome of Cyperus rotundus Linn. Int. J. Pham. Technol. 1: 42-46.

Yimer, M., Y. Zenebe, W. Mulu, B. Abera and J. M. Saugar. 2017. Molecular prevalence of Entamoeba histolyticaldispar infection among patients attending four health centres in North-West Ethiopia. Trop. Doct. 47: 11-15. 